\title{
PERFORMANCE EVALUATION OF POWER WEEDER IN SANDY SOILS AND DEVELOPMENT OF WEED RAKE
}

\section{RUMANDLA SANDEEP KUMAR, K. V. S. RAMI REDDY \& M. N. K. R. GURUDATT}

Department of Farm Machinery and Power, College of Agricultural Engineering, Acharya N. G. Ranga Agricultural University, Bapatla, Guntur, Andhra Pradesh, India

\begin{abstract}
Weeding consists of uprooting and removal of unwanted plants which grow in a field with a cultivated crop competing with the crops for moisture and plant nutrients. Weeding is essential to improve productivity of field crops. Manual weeding with local tool is most common practice in the vegetable crops. Suitable mechanization technology is needed to reduce drudgery and to enhance the timeliness of operation. Power weeder has been evaluated for its field performance in comparison with wheel hoe and traditional hand tool (powrah) taking into consideration their cost of operation in the farmers fields opposite to College of Agricultural Engineering, Bapatla. Besides uprooting of weeds, the removal of uprooted weeds will take more time and labour, hence a multipurpose weed rake was developed at the workshop of College of Agricultural Engineering, Bapatla. Field efficiency of power weeder, wheel hoe and powrah were $81.36 \%, 61.88 \%$ and $89 \%$ respectively. The power weeder had the lowest weeding time 20.24 h/ha, maximum coverage area $0.049 \mathrm{ha} / \mathrm{h}$, over wheel hoe and traditional method. The weeding efficiency of power weeder, wheel hoe and traditional method reported $82.89 \%, 79.59 \%$ and $97.21 \%$, respectively, with the cost of operation of Rs. 1676/ha, Rs $889 / \mathrm{ha}$ and Rs 3990/ha. Cost of operation of developing Weed Rake was very much less than traditional methods.

Keywords: Drying Time, Weeding, Weeding Efficiency, Field Capacity \& Weed Rake
\end{abstract}

Received: Aug 27, 2017; Accepted: Sep 15, 2017; Published: Oct 04, 2017; Paper Id.: IJASROCT201751

\section{INTRODUCTION}

Weeding is one of the most important farm operations in the crop production system. Weeding consists of removal and disposal of unwanted plants, which grow in a field with the cultivated crop, compete with the crop plants for nutrients and other growth factors. In the absence of an effective control measure, weeds, remove 30-40 $\%$ of applied nutrients resulting in a significant yield reduction (Dryden and Krishnamurthy, 1977). Control of weeds requires a lot of human labor, often several weeding are necessary to keep the crop weed free. Reduction in yield due to weed alone is estimated to be $16-42 \%$ depending on crop and location and involves $1 / 3$ rd of the cost of cultivation (Rangasamy et al, 1993). The most common methods of weed control are mechanical, chemical, biological and cultural methods. Out of these four methods, mechanical weeding either by hand tools or weeders are most effective in both dry land and wetland. Besides, mechanical weeding keeps the soil surface loose by producing soil mulch. This is stirring of shallow $(30 \mathrm{~mm}-50 \mathrm{~mm})$ top layer of soil such that this top layer of loose soil does not expose the moist sub surface, thus reduce the evaporation and gives better aeration at times, it also absorbs light shower of rain which would otherwise be lost by evaporation.

Manual weeding is the most common practice adopted in India. Manual weeding requires huge labor force, can give a clean weeding, but it is a slow process. Weeding accounts for about $25 \%$ of the total labor requirement 
(900-1200 man hours/hectare) during a cultivation season (YADAV and PUND, 2007). In India this operation is mostly performed manually with khurpi or trench hoe that requires higher labor input and also very tedious and time consuming process. So, a study was conducted to find out the performance of power weeder to compare to wheel hoe and traditional hand tool (powrah) and also, their cost of operation was taken into the consideration, by the operation weeders in between the rows of egg plant (Brinjal) field. Besides, uprooting of weeds, the removal of uprooted weeds will take more time and labor. Hence, a hand operated multipurpose weed rake was developed at College of Agricultural Engineering Workshop, Bapatla and accordingly, the study was conducted to fulfill the objectives like to evaluate the performance of power weeder, with respective to wheel hoe and local hand tool (powrah), to estimate the cost of operation of selected three weeders and development of suitable implement (weed rake), for collection of uprooted weeds.

\section{MATERIALS AND METHODS}

The pigeon pea dhal, vegetables like tomatoes and green pepper were procured from the local market. It was cleaned to remove foreign matter and inferior quality.

\section{Study Area}

The Farmers' fields, opposite to College of Agricultural Engineering, Bapatla were selected to conduct the experiments with the Power weeder, wheel hoe and Powrah.

\section{IMPLEMENTS SELECTED FOR EVALUATION}

\section{Power Weeder}

A power weeder ("Nikkari mini cultivator" manufactured by Nikkari Co, Ltd, Japan) was selected for the study (figure A.1.1). The power weeder was fitted with a $1.4 \mathrm{hp} \mathrm{engine} \mathrm{(make} \mathrm{Mitsubishi,} \mathrm{Japan)} \mathrm{on} \mathrm{mainframe} \mathrm{(25.6} \mathrm{cc),} \mathrm{with} \mathrm{an}$ axial through gears case with reduced speed ratio (1:35). A resistance bar is employed to disengage the rotary wheel, while in operation condition and also acts like a stand, while in resting position. The throttle was provided in right side of the handle, to control speed of the engine. Rotary is providing with wheel of $230 \mathrm{~mm}$ diameter, width of $240 \mathrm{~mm}$, depending on necessity. The machine can run on 4,3 , and 2 wheels, with the following widths.

- 4 wheels width $25.4 \mathrm{~cm}$.

- 3 wheels width $20.32 \mathrm{~cm}$.

- 2 wheels width $5.08 \mathrm{~cm}$.

These wheels fitted to axle have six sharp blades. These blades themselves aid in moving forward, while operating in the field.

\section{Wheel Hoe}

The wheel hoe is generally used for inter-culture, in between rows of crops (figure A.1.2). It has a light wheel of diameter of eight spikes, attached to two handles of mild steel to which a working tool is attached. The wheel assists in guiding the implement and in maintaining proper depth.

\section{Traditional Hand Tool (Powrah)}

Powrah (figure A.1.3) is the most popular weeding tool, used to cultivate very small areas. It consists of a wide 
thin cutting blade attached to handle. The weight of powrah is $1.5 \mathrm{~kg}$, front cutting edge width $220 \mathrm{~mm}$, blade length is 250 mm.

\section{Development of Weed Rake}

Keeping in view the planting geometry and the agronomical treatments required for better growth of crops, a multi crop inter cultivation, weed rake was developed to suit the requirements of small farmers.

\section{Components of Weed Rake}

Weed rake consists of following components (Figure A.1.4)

- Tool bar (frame),

- Fingers,

- Ferrule and

- Handle.

\section{Tool Bar (Frame)}

The toolbar is made of galvanized iron pipe of three pieces, on which semicircular fingers are welded, which are made from three pieces (figure A.1.5). The middle piece is $230 \mathrm{~mm}$ length, made up to $20 \mathrm{~mm}$ diameter galvanized iron pipe. Two end pieces, each of $95 \mathrm{~mm}$ length made of $20 \mathrm{~mm}$ diameter galvanized iron pipe. The end pieces are attached to the middle piece, with the help of galvanized iron pipe of $30 \mathrm{~mm}$ diameter, to form total length of $42 \mathrm{~mm}$. The weed rake can be used in the crop spacing, ranging from $200 \mathrm{~mm}$ to $400 \mathrm{~mm}$. The end pieces can be removed, when it is to be operated in a narrow crop up to $300 \mathrm{~mm}$.

\section{Fingers}

Nine semi circular fingers, fixed on a circular tool bar at the spacing of $50 \mathrm{~mm}$. Each finger is of 6 mm diameter, mild steel rod is bent in the half circle of $150 \mathrm{~mm}$ diameter. The cutting edge of the finger is properly sharpened and bent to $25^{\circ}$ rake angle. The fingers are welded soundly to the tool bar. (Figure A.1.6).

\section{Ferrule}

The ferrule is made from galvanized iron pipe of $20 \mathrm{~mm}$ diameter and $2 \mathrm{~mm}$ pipe wall thickness and $150 \mathrm{~mm}$ long. It is welded firmly to the tool bar arm in the correct position, at $35^{\mathrm{O}}$ with the horizontal plane. (Figure, A.1.7).

\section{Handle}

Matured, sound, straight and adequately seasoned bamboo is used to make as a handle (figure A.1.8). An inter-nodal distance of bamboo is $230 \mathrm{~mm}(<380 \mathrm{~mm})$ and the diameter of the bamboo at the ferrule is $20 \mathrm{~mm}$ and 30 $\mathrm{mm}$, on the grip side. Length of the handle is taken as $1600 \mathrm{~mm}$. The handle is fixed in to ferrule, with the help of $6 \mathrm{~mm}$ bolts rigidly.

Parameters of weed rake are presented in Table 2.1 
Table 2.1: Parameters of Weed Rake

\begin{tabular}{|l|c|}
\hline \multicolumn{1}{|c|}{ Details } & Weed Rake \\
\hline Working width, mm & 450 \\
\hline Weight, kg & 1.82 \\
\hline $\begin{array}{l}\text { Height of handle from } \\
\text { ground level, mm }\end{array}$ & $800-1000$ \\
\hline Cost, Rs & 300 \\
\hline
\end{tabular}

The Functional and Economical Aspects of Weed Rake

- Extent of achieving timeliness of operation

- Improvement in quality of work.

- Reduction in drudgery.

- Improvement in safety.

- Cost effectiveness.

The following field tests were carried out in the research fields, to evaluate the performance of the different weeders for weeding operation. The field tests were carried out, to ascertain the following performance parameters.

\section{Speed of Operation}

Operational speed of weeders was calculated by fixing two poles, $20 \mathrm{~m}$ apart in the test plot. The time required to travel the $20 \mathrm{~m}$ distance was recorded, to calculate the average value of time. From this time, the effective field capacity has been estimated.

\section{Actual Field Capacity}

Time consumed for real work $\left(\mathrm{t}_{\mathrm{p}}\right)$ and that lost for other activities, such as turning at headlands, blade cleaning when clogging with weeds $\left(\mathrm{t}_{\mathrm{c}}\right)$ was measured by stopwatch and recorded for calculation.

$$
\mathrm{a}=\frac{\mathrm{A}}{\mathrm{t}_{\mathrm{p}}+\mathrm{t}_{\mathrm{c}}}
$$

Where,

$a=$ actual field capacity $(\mathrm{ha} / \mathrm{h})$

$A=$ area covered, ha

$t_{P}=$ Productive time, $\mathrm{h}$

$t_{c}=$ Unproductive time, $\mathrm{h}$

\section{Theoretical Field Capacity}

It is the rate of field coverage of the implement blade, on hundred percent of the time at the rated speed and a covering hundred percent of rated width. It is given by the formula.

$$
\mathrm{f}=\frac{(\mathrm{W}+\mathrm{S})}{10}
$$

Where 
$\mathrm{f}=$ Theoretical field capacity $(\mathrm{ha} / \mathrm{h})$

$\mathrm{W}=$ Width $(\mathrm{m})$

$\mathrm{S}=$ Speed of operation $(\mathrm{km} / \mathrm{h})$

\section{Fuel Consumption}

Fuel consumption was estimated by keeping the machine on a level platform and fuel was filled to full capacity mark. The amount of fuel required refilling the fuel tank again, after a one-hour continuous operation upto the full capacity mark, with the help of measuring jar and fuel consumption per hour was calculated.

\section{Weeding Efficiency}

Weeding efficiency was calculated by using the following formula

$\mathrm{e}=\frac{\left(\mathrm{W}_{1}+\mathrm{W}_{2}\right)}{\mathrm{W}_{1}} \mathrm{X} 100$

Where,

$e=$ Weeding efficiency, per cent

$\mathrm{W}_{1}=$ Number of weeds $/ \mathrm{m}^{2}$ before weeding

$\mathrm{W}_{2}=$ number of weeds $/ \mathrm{m}^{2}$ after weeding

\section{Plant Damage}

Plant damage percent is measured by using following relation

$$
\mathrm{q}=\frac{\mathrm{n}_{1}}{\mathrm{n}_{2}} \times 100
$$

Where,

$q=$ plant damage per cent

$n_{1}=$ Number of plants damaged in a 10 m row length after weeding

$n_{2}=$ Number of plants in a $10 \mathrm{~m}$ row length before weeding

\section{Cost of Operation}

Cost of operation was calculated by considering depreciation, interest, housing, repair and maintenance, fuel cost and operator wages, for the power weeder, whereas for the wheel hoe and traditional local tool, only the operator wages are taken into the consideration.

\section{RESULTS AND DISCUSSIONS}

\section{Speed of Operation}

Speed of operation of local tool (powrah), wheel hoe and power weeder in an experimental plot are presented in Table 3.1 
Table 3.1: Speed of Operation of Local Tool (Powrah), Wheel Hoe and Power Weeder

\begin{tabular}{|l|c|c|c|c|}
\hline Replication Number & Trail 1 & Trail 2 & Trail 3 & Average \\
\hline Local tool (kmph) & 0.24 & 0.25 & 0.25 & 0.24 \\
\hline Wheel hoe (kmph) & 1.41 & 1.61 & 1.46 & 1.49 \\
\hline Power weeder (kmph) & 2.42 & 2.25 & 2.57 & 2.41 \\
\hline
\end{tabular}

\section{Actual Field Capacity}

The actual field capacities of local tool (powrah), wheel hoe and power weeder in an experimental plot are presented in Table 3.2, Table 3.3 and Table 3.4

Table 3.2: Data and Analysis of Actual Field Capacities of Local Tool

\begin{tabular}{|c|c|c|c|c|}
\hline $\begin{array}{c}\text { Replication } \\
\text { Number }\end{array}$ & $\begin{array}{c}\text { Area of the Plot } \\
\text { (Sq. M) }\end{array}$ & $\begin{array}{c}\text { Time Taken to Cover } \\
\text { an Area of 200 Sq. M } \\
\text { (Min) }\end{array}$ & $\begin{array}{c}\text { Field Capacity } \\
\text { (Ha/H) }\end{array}$ & $\begin{array}{c}\text { Field } \\
\text { Capacity } \\
\text { (Ha/Day) }\end{array}$ \\
\hline 1 & 200 & 256 & 0.00469 & 0.0375 \\
\hline 2 & 200 & 257 & 0.00467 & 0.0373 \\
\hline 3 & 200 & 255 & 0.0047 & 0.0376 \\
\hline Average & $\mathbf{2 0 0}$ & $\mathbf{2 5 6}$ & $\mathbf{0 . 0 0 4 7}$ & $\mathbf{0 . 0 3 7 5}$ \\
\hline
\end{tabular}

Table 3.3: Data and Analysis of Actual Field Capacities of Wheel Hoe

\begin{tabular}{|c|c|c|c|c|}
\hline $\begin{array}{c}\text { Replication } \\
\text { Number }\end{array}$ & $\begin{array}{c}\text { Area of the } \\
\text { Plot (Sq. M) }\end{array}$ & $\begin{array}{c}\text { Time Taken to } \\
\text { Cover an Area of } \\
\text { 200 Sq. M (Min) }\end{array}$ & Field Capacity (Ha/H) & $\begin{array}{c}\text { Field } \\
\text { Capacity } \\
\text { (Ha/Day) }\end{array}$ \\
\hline 1 & 200 & 55 & 0.0221 & 0.176 \\
\hline 2 & 200 & 54 & 0.0221 & 0.177 \\
\hline 3 & 200 & 54 & 0.0222 & 0.177 \\
\hline Average & $\mathbf{2 0 0}$ & $\mathbf{5 4}$ & $\mathbf{0 . 0 2 2 1}$ & $\mathbf{0 . 1 7 7}$ \\
\hline
\end{tabular}

Table 3.4: Data and Analysis of Actual Field Capacities of Power Weeder

\begin{tabular}{|c|c|c|c|c|}
\hline $\begin{array}{c}\text { Replication } \\
\text { Number }\end{array}$ & $\begin{array}{c}\text { Area of the } \\
\text { Plot (Sq. } \\
\text { M) }\end{array}$ & $\begin{array}{c}\text { Time Taken to } \\
\text { Cover An Area of } \\
\text { 200 Sq. M (Min) }\end{array}$ & $\begin{array}{c}\text { Field Capacity } \\
\text { (Ha/H) }\end{array}$ & $\begin{array}{c}\text { Field } \\
\text { Capacity } \\
\text { (Ha/Day) }\end{array}$ \\
\hline 1 & 200 & 24 & 0.0495 & 0.396 \\
\hline 2 & 200 & 24 & 0.050 & 0.4 \\
\hline 3 & 200 & 25 & 0.0487 & 0.389 \\
\hline Average & $\mathbf{2 0 0}$ & $\mathbf{2 4}$ & $\mathbf{0 . 0 4 9 4}$ & $\mathbf{0 . 3 9}$ \\
\hline
\end{tabular}

\section{Field Efficiency}

Field efficiencies of local tool (powrah), wheel hoe and power weeder were observed in an experimental plot. The results are presented in Table 3.5.

\section{Plant Damage}

The plant damage was observed in the length of $20 \mathrm{~m}$, having 17 average numbers of plants and the results are presented in Table 3.6.

\section{Weeding Efficiency}

Weeding efficiencies of local tool (powrah), wheel hoe and power weeder were observed in an experimental plot. The results are presented in Table 3.7, Table 3.8 and Table 3.9. 
Table 3.5: Data and Analysis of the Field Efficiencies of Local Tool (Powrah), Wheel Hoe and Power Weeder

\begin{tabular}{|l|c|c|c|}
\hline \multicolumn{1}{|c|}{ Type of Weeder } & $\begin{array}{c}\text { Theoretical } \\
\text { Field } \\
\text { Capacity(Ha/H) }\end{array}$ & $\begin{array}{c}\text { Actual Field } \\
\text { Capacity } \\
\text { (Ha/H) }\end{array}$ & $\begin{array}{c}\text { Field } \\
\text { Efficiency } \\
(\%)\end{array}$ \\
\hline Local tool (powrah) & 0.00528 & 0.0047 & 89 \\
\hline Wheel hoe & 0.0357 & 0.0221 & 61.88 \\
\hline Power weeder & 0.0612 & 0.0494 & 81.36 \\
\hline
\end{tabular}

Table 3.6: Data and Analysis of the Plant Damage

\begin{tabular}{|l|c|c|c|}
\hline Replication Number & Local Tool & Wheel Hoe & $\begin{array}{c}\text { Power } \\
\text { Weeder }\end{array}$ \\
\hline Trail 1 & 0 & 1 & 2 \\
\hline Trail 2 & 0 & 1 & 4 \\
\hline Trail 3 & 0 & 2 & 2 \\
\hline Average & 0 & 1.3 & 2.66 \\
\hline Plant damage (\%) & 0 & 7.84 & 15.58 \\
\hline
\end{tabular}

Table 3.7: Data and Analysis of Weeding Efficiencies of Local Tool (Powrah)

\begin{tabular}{|c|c|c|c|c|}
\hline $\begin{array}{c}\text { Replication } \\
\text { No }\end{array}$ & $\begin{array}{c}\text { Area of Plot } \\
\text { (Sq.M) }\end{array}$ & $\begin{array}{c}\text { Number of } \\
\text { Weeds Before } \\
\text { Weeding in An } \\
\text { Area of } \mathbf{1 m}^{\mathbf{2}}\end{array}$ & $\begin{array}{c}\text { Number of } \\
\text { Weeds After } \\
\text { Weeding in An } \\
\text { Area of } \mathbf{1 ~ m}^{\mathbf{2}}\end{array}$ & $\begin{array}{c}\text { Weeding } \\
\text { Efficiency } \\
(\mathbf{\%})\end{array}$ \\
\hline 1 & 1 & 267 & 6 & 97.75 \\
\hline 2 & 1 & 221 & 8 & 96.38 \\
\hline 3 & 1 & 200 & 5 & 97.5 \\
\hline average & $\mathbf{1}$ & $\mathbf{2 2 9}$ & $\mathbf{6}$ & $\mathbf{9 7 . 2 1}$ \\
\hline
\end{tabular}

Table 3.8: Data and Analysis of Weeding Efficiencies of Local Tool Wheel Hoe

\begin{tabular}{|c|c|c|c|c|}
\hline $\begin{array}{c}\text { Replication } \\
\text { No }\end{array}$ & $\begin{array}{c}\text { Area } \\
\text { of Plot } \\
\text { (Sq.M) }\end{array}$ & $\begin{array}{c}\text { Number of } \\
\text { Weeds Before } \\
\text { Weeding in an } \\
\text { Area of } \mathbf{1 m}^{\mathbf{2}}\end{array}$ & $\begin{array}{c}\text { Number of } \\
\text { Weeds After } \\
\text { Weeding in } \\
\text { an Area of } \\
\mathbf{1 ~ m}^{\mathbf{2}}\end{array}$ & $\begin{array}{c}\text { Weeding } \\
\text { Efficiency } \\
\mathbf{( \% )}\end{array}$ \\
\hline 1 & 1 & 256 & 50 & 80.4 \\
\hline 2 & 1 & 218 & 40 & 81.65 \\
\hline 3 & 1 & 235 & 55 & 76.59 \\
\hline average & $\mathbf{1}$ & $\mathbf{2 3 6}$ & $\mathbf{4 8}$ & $\mathbf{7 9 . 5 4}$ \\
\hline
\end{tabular}

Table 3.9: Data and Analysis of Weeding Efficiencies of Local Tool Power Weeder

\begin{tabular}{|c|c|c|c|c|}
\hline $\begin{array}{c}\text { Replication } \\
\text { No }\end{array}$ & $\begin{array}{c}\text { Area of } \\
\text { Plot } \\
\text { (Sq.M) }\end{array}$ & $\begin{array}{c}\text { Number of Weeds } \\
\text { Before Weeding in } \\
\text { an Area of } \mathbf{1 m}^{\mathbf{2}}\end{array}$ & $\begin{array}{c}\text { Number of } \\
\text { Weeds After } \\
\text { Weeding in An } \\
\text { Area of } \mathbf{1 m}^{\mathbf{2}}\end{array}$ & $\begin{array}{c}\text { Weeding } \\
\text { Efficiency } \\
(\mathbf{\%})\end{array}$ \\
\hline 1 & 1 & 246 & 41 & 83.33 \\
\hline 2 & 1 & 239 & 40 & 83.26 \\
\hline 3 & 1 & 235 & 42 & 82.1 \\
\hline Average & $\mathbf{1}$ & $\mathbf{2 4 7}$ & $\mathbf{4 1}$ & $\mathbf{8 2 . 8 9}$ \\
\hline
\end{tabular}




\section{Cost of Operations}

\section{Cost of Uprooting the Weeds}

Table 3.10: Data and Analysis of the Cost of Operation of Local Tool (Powrah), Wheel Hoe and Power Weeder

\begin{tabular}{|l|c|c|}
\hline $\begin{array}{c}\text { Name of the } \\
\text { Implement }\end{array}$ & $\begin{array}{c}\text { Hours to Work by } \\
\text { Operator Per Hectare } \\
\text { (H/Ha) }\end{array}$ & $\begin{array}{c}\text { Cost of Operation Per } \\
\text { Hectare (Rs/Ha) }\end{array}$ \\
\hline Local tool (powrah) & 212.76 & 3990 \\
\hline Wheel hoe & 45.24 & 849 \\
\hline Power weeder & 20.24 & 1676 \\
\hline
\end{tabular}

\section{Development of Weed Rake}

To suit the small farmers' needs, a weed rake was developed at the workshop of College of Agricultural Engineering, Bapatla, as discussed in the previous chapter. The only cost of operation is worked out and compared to traditional methods of weeding.

\section{Cost of Removal of Uprooted Weeds}

Labor charges for removal of uprooted weeds by traditional methods (manually) is Rs 4000/ha and weed rake is Rs $382.5 /$ ha, the cost of removal of uprooted weeds has drastically reduced, by using a weed rake that is $97.82 \%$.

\section{CONCLUSIONS}

It is inferred that, weeding is an important operation for field crops and if done properly with efficient, high output, low coast and easy to operate weeding equipment, a significant yield increase could be achieved. From above studies, it is concluded that, Nikari power weeder is an efficient and most promising weeding machine for medium and large farmers. The feedback regarding the Nikkari power weeder is given below:

- The initial cost of power weeder is high.

- The cost of weeding is reduced.

- The labor requirement for weeding can be reduced.

- 20.24 man-hours are required to cover one-hector area, as compared to 212.76 man-hour for weeding, one-hector by convectional practice.

- Frequent cleaning of weeds wound, over the rotary tine is required.

Field efficiencies and weeding efficiencies for the three weeders namely, power weeder, wheel hoe and powrah were determined along with their cost of operation. A weed rake was also developed, for the removal of uprooted weeds from the field, the conclusions drawn from the study are given below

- $\quad$ Field efficiencies of power weeder, wheel hoe and powrah are $81.36 \%, 61.88 \%$ and $89 \%$ respectively.

- $\quad$ Plant damage observed for power weeder, wheel hoe and powrah are $15.58 \%, 7.84 \%$ and $0 \%$ respectively.

- Weeding efficiencies of power weeder, wheel hoe and powrah are $82.89 \%, 79.54 \%$ and $97.21 \%$ respectively.

- Cost of operation of power weeder, wheel hoe and powrah are Rs1676/ha, Rs849/ha and Rs3990/ha respectively. 
- Cost of operation of developing weed rake was very much less than the traditional method.

- Bending posture, adopted in conventional method is eliminated by use of power weeder and weed rake. Hence, from an ergonomic point of view, the workers will be relieved of back problems.

\section{REFERENCES}

1. Jagvir Dixit and Intikhab Syed. (2008). Field elevation of power weeder for rain -fed crops in Kashmir valley. Agricultural mechanization in Asia, Africa and Latin America. 39 (1): (53-56).

2. Padole, Y.B. (2007). Performance evolution of rotary power weeder. Agricultural engineering today. 31 (3\&4): $30-33$.

3. Tajuddin, A. (2006). Design, development and testing of an engine operated weeder. Agricultural engineering today. 30(5,6): 25-29.

4. Anonymous. 2004. Data book for agricultural machine design. Book number CIAE/2004/1. Central institute of agricultural engineering, Bhopal, India.

5. Indian standard specifications for powrahs. IS: 1759-1961.

6. Indian standard specifications for garden rake. IS: 12559-1963.

7. Indian standard specifications for three tined hand hoe. IS:3292-1965, ISI

\section{APPENDIX}

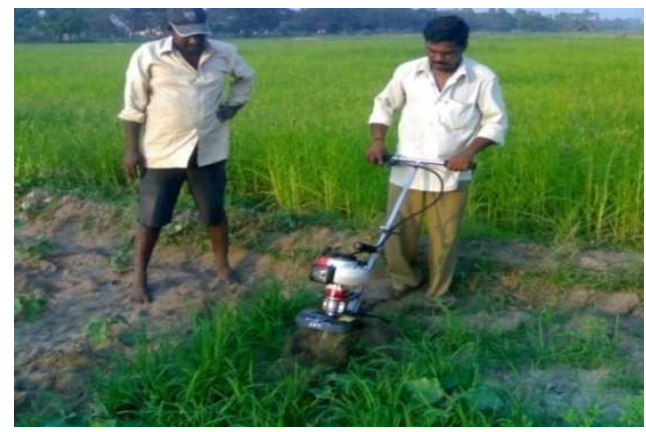

Figure A.1.1: Weeding with Power Weeder

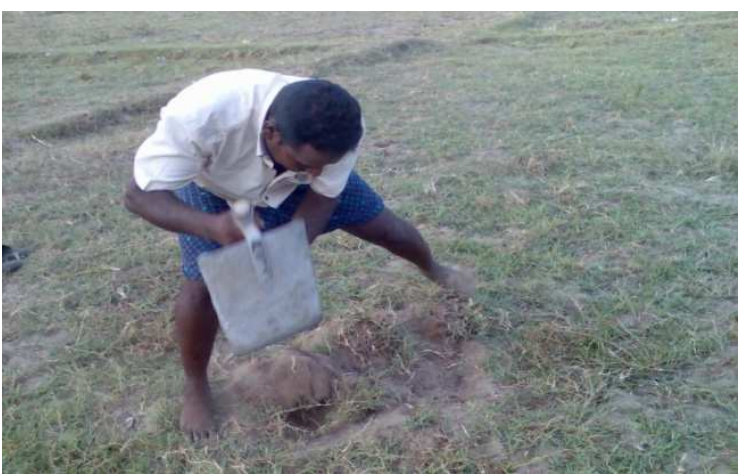

Figure A.1.3: Weeding with powrah

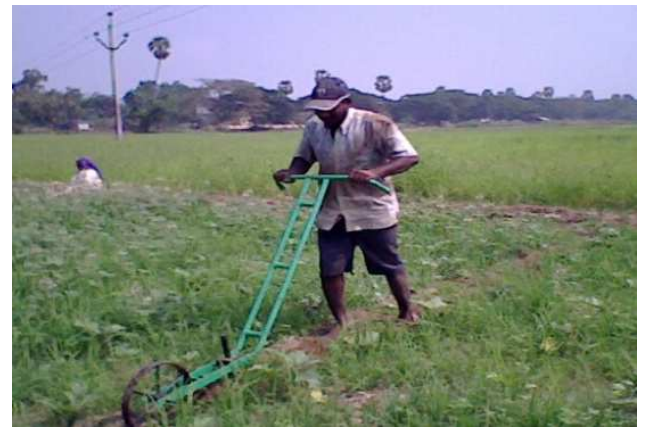

Figure A.1.2: Weeding with Wheel Hoe

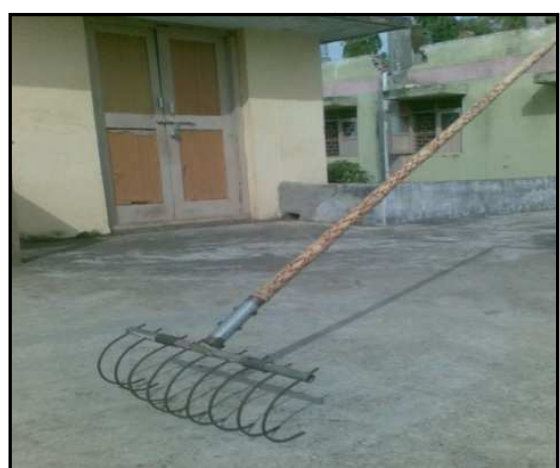

Figure A.1.4: Weeding with wheel hoe 


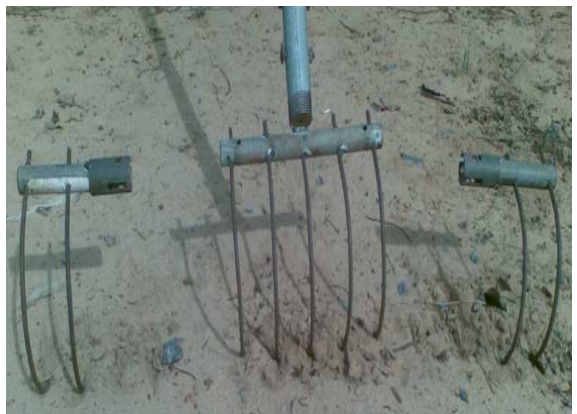

Figure A.1.5: Tool Bar (Frame)

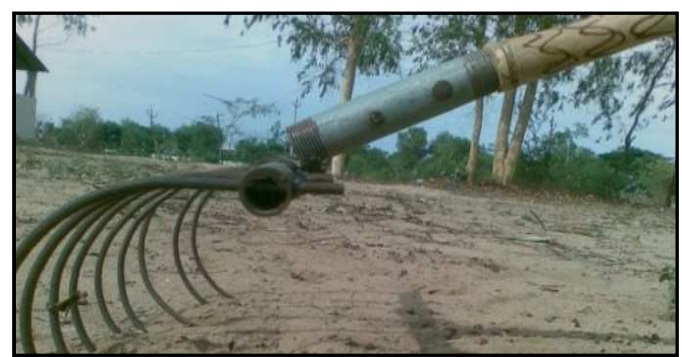

Figure A.1.7: Ferule

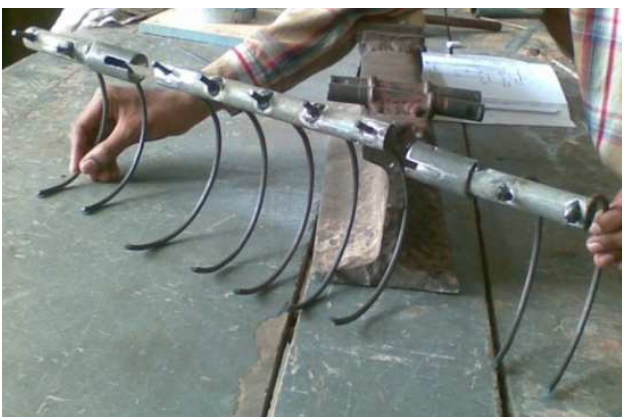

Figure A.1.6: Weeding with Powrah

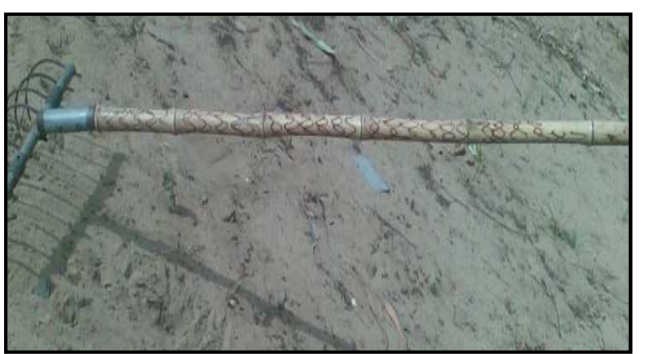

Figure A.1.8: Handle 